\title{
ANALISIS FAKTOR-FAKTOR KELUARGA YANG BERHUBUNGAN DENGAN PERILAKU AGRESIF PADA REMAJA DI KOTA MALANG (DENGAN PENDEKATAN TEORI STRUKTURAL FUNGSIONAL KELUARGA) Dian Pitaloka Priasmoro ${ }^{1}$, Edi Widjajanto ${ }^{2}$, Lilik Supriati ${ }^{3}$ \\ ${ }^{1}$ Poltekkes RS dr. Soepraoen Malang \\ ${ }^{2,3}$ Staf Pengajar Fakultas Kedokteran Universitas Brawijaya Malang
}

\begin{abstract}
ABSTRAK
Remaja memiliki tugas perkembangan yang harus dicapai yaitu identitas diri (identity). Tugas ini menekankan pentingnya rasa percaya diri. Ketidak berhasilan dalam mencapai tugas perkembangan akan mengakibatkan kebingungan peran (role confusion) yang dapat menyebabkan perilaku menyimpang seperti perillaku agresif. Perilaku ini muncul sebagai interaksi dari beberapa faktor seperti individu, keluarga, sosiokultural, dan paparan. Pendekatan teori struktural fungsional keluarga memandang terjadinya,perubahan fungsi, dukungan, dan lingkungan didalam keluarga dapat mempengaruhi anggota keluarga. Tujuan penelitian ini adalah menganalisis faktor keluarga (fungsi, dukungan, lingkungan didalam keluarga) yang berhubungan dengan perilaku agresif. Metode dalam penelitian ini deskriptif korelasional dengan pendekatan cross sectional. Jumlah sampel 83 responden diambil dengan proportional stratified random sampling. Alat ukur yang digunakan kusioner fungsi Family Assesment Device (FAD), dukungan Model Friedman, lingkungan Family Environment System (FES), dan perilaku agresif Aggression Questionnaire(AQ). Hasil penelitian menunjukkan mean skor fungsi keluarga 36,24 (59\%) dalam kategori fungsional keluarga, dukungan keluarga 58,13 (58\%) kategori dukungan sedang, lingkungan keluarga 72,18 (94\%) kategori lingkungan terstruktur, dan perilaku agresif 76,24 (75\%) kategori agresif diatas rata-rata. Analisis korelasi dengan Pearson didapatkan faktor yang berhubungan dengan perilaku agresif $p$-value $<\alpha 0,05$ adalah fungsi ( $p$-value=0,001,r=-0,361), dukungan ( $p$-value $=0,000, \mathrm{r}=-0,416)$, dan lingkungan ( $p$-value $=0,000, r=-0,37)$. Analisis multivariat dengan regresi linier berganda didapatkan sig $0,000<0,05$, dan koefisien fungsi keluarga paling besar $(-0,390)$. Sehingga dapat disimpulkan bahwa secara bersama-sama faktor fungsi, dukungan, dan lingkungan keluarga berhubungan secara bermakna dengan perilaku agresif. Peningkatan faktor fungsi, dukungan dan lingkungan keluarga akan menurunkan perilaku agresif. Dan faktor fungsi keluarga adalah yang paling berkontribusi atau berhubungan dengan perilaku agresif.
\end{abstract}

Kata Kunci: Faktor-Faktor Keluarga, Perilaku Agresif, Remaja, Teori Struktural Fungsional Keluarga

\section{ABSTRACT}

Teenagers have a developmental task that must be achieved, namely identity (identity). This task emphasizes the importance of self-confidence. The lack of success in achieving the developmental tasks will cause confusion role that can lead to deviant behavior such as aggressive. This behavior emerged as the interaction of several factors such as the individual, family, sociocultural, and aggressive exposure. Structural-functional theory approach to looking at the family, changes in functionality, support, and the environment in the family can affect family members. Purpose of this study was to analyze family factors (functionality, support, within their family environment) that is associated with aggressive behavior. Method used descriptive correlation with cross sectional sample of 83 respondents were taken by proportional stratified random sampling. Measuring instruments used questionnaire function Family Assessment Device (FAD), family support Model Friedman, environment Family Environment System (FES), and aggressive behavior Aggression Questionnaire (AQ). Results showed a mean score of family functions 36.24 (59\%) in the category of functional family, family support 58.13 (58\%) categories of support being, family environment 72.18 (94\%) categories, structured environment, and aggressive behavior 76, 24 (75\%) categories aggressive than average. Pearson correlation analysis found that factors associated with aggressive behavior $p$-value $<0.05$ is a function $\alpha$ ( $p$-value $=0.001, r=-0.361)$, support ( $p$ value $=0.000, r=-0.416)$, and the environment ( $p$-value $=0.000, r=-0.37)$. Multivariate analysis with multiple linear regression obtained sig $0.000<0.05$, and most families function coefficient (-0.390). Conclusion taken together factor function, support, and family environment significantly associated with aggressive behavior. Increased factor function, support and family environment will reduce aggressive behavior. And family functioning factor is that most contribute to or associated with aggressive behavior.

Keywords: Factors Family, Aggressive Behavior, Adolescent, Structural Theory of Functional Family

Jurnal IImu Keperawatan, Vol: 4, No.2 ; Korespondensi : Dian Pitaloka Priasmoro. Poltekkes RS Dr. Soepraoen. Alamat : Jl. S. Supriadi No. 22 Kec. Sukun Kota Malang .Email. dianaska cute@yahoo.com/ HP.081233199747.

Jurnal Ilmu Keperawatan - Volume 4, No. 2 November 2016 


\section{PENDAHULUAN}

Tumbuh kembang manusia merupakan suatu proses unik, yang terjadi secara dinamis, serta mengikuti sebuah pola tertentu (FitzgeraldYau,Hale\&Viner 2014). Salah satu tahapan perkembangan tersebut adalah masa remaja (12-18) tahun(Ballard, Kennedy, \& O’Brien, 2014). Pada masa ini remaja memiliki tugas perkembangan yang harus dicapai yaitu identitas diri (identity) yang meliputi peran, tujuan, keunikan dan ciri khas diri (Keliat, et al, 2014). Tugas perkembangan tersebut menekankan kepada pentingnya rasa percaya diri (Ballard, Kennedy, \& O’Brien, 2014).

Ketidakberhasilan dalam mencapai tugas perkembangan tersebut dapat menyebabkan remaja mengalami kebingungan peran (role confusion) (Keliat, et al, 2014). Yang menyebabkan berbagai perilaku menyimpang seperti perilaku agresif (Williford, et al, 2011). Masalah perilaku anak dan remaja seperti perilaku agresif dapat berkembang menjadi gejala positif skizotipal (Fagel, 2014).

Menurut survei yang dilakukan Khalid, Ford, \& Maughan pada tahun 1973-2004 dengan metode Kohort di The child and adolescent department of the Mandsley Hospital London dari 1.558 anak dan remaja yang memiliki masalah perilaku didapatkan 1.346 (86\%) menunjukkan perilaku agresif menetap, 173 (11\%) menunjukkan gejala psikosis, dan 39 (3\%) menunjukkan terjadinya bentuk gangguan perilaku yang lain pada masa dewasa (Khalid, Ford, \& Maughan, 2012).

Perilaku agresif pada dasarnya dipandang sebagai sesuatu yang alami. Namun dapat menjadi patologis bila berlangsung lama atau dalam periode waktu tertentu (I Wahdan, et al, 2013). Perilaku agresif muncul sebagai interaksi dari beberapa faktor seperti individu, keluarga, sosiokultural, dan paparan kekerasan (Caicedo \& Jones, 2014).

Intervensi positif harus diberikan kepada remaja sekaligus keluarga (Ballard, Kennedy, \& O’Brien, 2014). Karena pengalaman kehidupan anak dimulai dari keluarga. Dalam proses ini orang tua merupakan bagian penting dari proses perkembangan anak (Caicedo \& Jones, 2014). Pendekatan teori struktural fungsional keluarga memandang adanya perubahan fungsi, dukungan, dan lingkungan didalam keluarga dapat mempengaruhi anggota keluarga.

Survei awal yang dilakukan pada tanggal 1 Pebruari 2016 di salah satu SMP Negeri Kota Malang dari hasil dokumentasi serta wawancara dengan guru BK didapatkan data sejak bulan Nopember 2015 sampai Januari 2016 tercatat 215 laporan konsultasi siswa kelas VII. Sebagian besar melakukan pelanggaran disiplin seperti terlambat masuk sekolah, tidak mengikuti pelajaran, tidak masuk sekolah lebih dari 2 hari tanpa keterangan, berkata kasar, menonton film 
porno, berkelahi, merokok, serta merusak fasilitas sekolah. Berdasarkan data tersebut maka dipandang perlu dilakukan penelitian untuk menganalisis faktor-faktor keluarga yang berhubungan dengan perilaku agresif pada remaja di Kota Malang Dengan Pendekatan Teori Struktural Fungsional Keluarga.

\section{METODE}

Desain yang digunakan dalam penelitian ini adalah deskriptif korelasional, dengan pendekatan cross sectional. Populasi dan sampel dalam penelitian ini adalah remaja kelas VII di SMP N 2, 8, dan 17 Kota Malang yang tercatat melakukan pelanggaran di sekolah minimal 3 kali dalam 3 bulan terakhir serta memenuhi kriteria. Sampel diambil dengan teknik proportional stratified random sampling dengan jumlah 83 responden.

Instrumen yang digunakan adalah kuisioner fungsi Family Assesment Device(FAD), dukungan keluarga Model Friedman, lingkungan keluarga Family Environment System(FES), dan perilaku agresif Aggresssion Questionnare (AQ). Sebelum instrumen digunakan untuk mengambil data dilakukan uji validitas dengan Product Momen Pearson Correlation dan reliabilitas Alpha Chronbach's. Dan didapatkan hasil instrument valid dan reliable.
Penelitian dilakukan di SMP N 2, 8, dan 17 Kota Malang pada bulan Mei-Juni 2016 dengan pengisian kuisioner dan wawancara selama 45 menit. Data yang didapat selanjutnya dilakukan analisis univariat yang disajikan dalam bentuk mean, median, modus, standart deviasi, minimum, dan maksimum dan data katagorik disajikan dalam bentuk distribusi frekuensi dan prosentase. Bivariat dengan uji korelasi Pearson. Dan multivariat dilakukan dengan uji regresi linier.

\section{HASIL}

Data gambaran umum responden disajikan dalam bentuk narasi yaitu berdasarkan data hasil penelitian diketahui bahwa dari 83 responden, rata-rata berumur 13 tahun. Berjenis kelamin laki-laki sebanyak 67 orang $(80,7 \%)$, memiliki 1 saudara kandung sebanyak 32 orang (38,6\%). Anak pertama sebanyak 41 orang $(49,4 \%)$, memiliki hubungan baik dengan orang tua sebanyak 67 orang $(80,7 \%)$.

Pendidikan ayah responden adalah SMA sebanyak 43 orang $(51,8 \%)$, pekerjaan ayah responden sebagian besar adalah wiraswasta sebanyak 71 orang (85,5\%). Pendidikan ibu responden sebagian besar adalah SMA sebanyak 43 orang $(51,8 \%)$, ibu responden tidak bekerja sebanyak 60 orang (72,3\%). Penghasilan orang tua responden adalah dibawah UMR sebanyak 32 orang (38,6\%). 
Tinggal serumah dengan orang tua (ayah dan ibu) sebanyak 75 orang $(90,4 \%)$, tidak tinggal serumah dengan orang tua karena bercerai sebanyak 5 orang $(62,5 \%)$.

\section{Analisis Univariat}

Tabel 1. Karakteristik Faktor Keluarga

\begin{tabular}{lllll}
\hline Variabel & Mean & Median & Std.dev & $\begin{array}{l}\text { Min- } \\
\text { max }\end{array}$ \\
\hline $\begin{array}{l}\text { Skor } \\
\text { fungsi }\end{array}$ & $\mathbf{3 6 , 2 4}$ & $\mathbf{3 6 , 0 0}$ & $\mathbf{3 , 5 5 3}$ & $\mathbf{2 6 - 4 7}$ \\
$\begin{array}{l}\text { keluarga } \\
\begin{array}{l}\text { Skor } \\
\text { dukungan } \\
\text { keluarga }\end{array}\end{array}$ & $\mathbf{5 8 , 1 3}$ & $\mathbf{5 8 , 0 0}$ & $\mathbf{8 , 0 1 0}$ & $\mathbf{3 7 - 7 6}$ \\
$\begin{array}{l}\text { Skor } \\
\text { lingkungan } \\
\text { keluarga }\end{array}$ & $\mathbf{7 2 , 1 8}$ & $\mathbf{7 3 , 0 0}$ & $\mathbf{5 , 3 2 6}$ & $\mathbf{6 2 - 8 3}$ \\
\hline
\end{tabular}

(Sumber : Output Pengolahan Data SPSS 19,0

Juni 2016)

Pada tabel 1 diketahui bahwa dari 83 responden, mean skor fungsi keluarga adalah 36,24 (59\%) kategori fungsional keluarga, mean skor dukungan keluarga adalah 58,13 (58\%) kategori dukungan sedang, dan mean skor lingkungan keluarga adalah 72,18 (94\%) kategori lingkungan structuredness.

Tabel 2. Karakteristik Perilaku Agresif

\begin{tabular}{ccccc}
\hline Variabel & Mean & Median & Std.dev & $\begin{array}{c}\text { Min- } \\
\text { max }\end{array}$ \\
\hline Skor Perilaku & 76,24 & 77,00 & 6,557 & $\begin{array}{c}59- \\
92\end{array}$ \\
Agresif & & & & 92
\end{tabular}

(Sumber : Output Pengolahan Data SPSS 19,0

Juni 2016)

Berdasarkan tabel 2 diketahui dari 83 responden, mean skor perilaku agresif responden adalah 76,24 (75\%) kategori diatas rata-rata.

\section{Analisis Bivariat}

Sebelum dilakukan uji korelasi Pearson dilakukan uji normalitas data menggunakan uji Kolmogorov-Smirnov dengan nilai signifikan ( $p$-value) > 0,05 yang artinya penyebaran data normal.

Tabel 3. Hasil Uji Korelasi Pearson FaktorFaktor Keluarga Dengan Perilaku Agresif

\begin{tabular}{lccc}
\hline $\begin{array}{l}\text { Faktor-Faktor } \\
\text { Keluarga }\end{array}$ & $\mathbf{n}$ & $\boldsymbol{p}$-value & $\boldsymbol{R}$ \\
\hline $\begin{array}{l}\text { 1. } \\
\text { Fungsi } \\
\text { Keluarga }\end{array}$ & 83 & 0,001 & $-0,361$ \\
\hline $\begin{array}{l}\text { 2. Dukungan } \\
\text { Keluarga }\end{array}$ & 83 & 0,000 & $-0,416$ \\
\hline $\begin{array}{l}\text { 3. Lingkungan } \\
\text { Keluarga }\end{array}$ & 83 & 0,000 & $-0,379$ \\
\hline $\begin{array}{l}\text { (Sumber : Output Pengolahan Data SPSS 19,0 } \\
\text { Sumber }\end{array}$
\end{tabular}
Juni 2016).

Berdasarkan tabel 3 diperoleh data faktor fungsi keluarga menunjukkan 1) ada hubungan yang lemah antara peningkatan fungsi keluarga dengan penurunan perilaku agresif 2) ada hubungan sedang antara peningkatan dukungan keluarga dengan dengan penurunan perilaku agresif, dan 3) ada hubungan yang lemah antara peningkatan lingkungan keluarga dengan penurunan perilaku agresif.

\section{Analisis Multivariat}

Untuk melihat besarnya hubungan variabel independent dengan variabel dependent merupakan data numerik. 
sebesar $24 \%$, sebesar $76 \%$ sisanya dijelaskan

\begin{tabular}{clcccc}
\hline $\begin{array}{c}\text { Lang } \\
\text { kah }\end{array}$ & Variabel & Koefisien & $\begin{array}{c}\text { Koefisien } \\
\text { Korelasi }\end{array}$ & & $\mathbf{R}^{2}$ \\
\hline $\begin{array}{c}\text { Lang } \\
\text { kah } \\
1\end{array}$ & Fungsi & -0.390 & -0.231 & 0.027 & \\
& Keluarga & & & & \\
& $\begin{array}{l}\text { Dukunga } \\
\text { n }\end{array}$ & -0.188 & -0.247 & 0.027 & \\
& & & & \\
& Keluarga & & & & \\
& Lingkung & -0.261 & -0.227 & 0.035 & \\
& $\begin{array}{l}\text { an } \\
\text { Keluarga }\end{array}$ & & & & \\
& Konstant & 119.73 & & 0.000 & 0,24 \\
& a & 0 & & & \\
\hline
\end{tabular}

(Sumber : Output Pengolahan Data SPSS 19,0 Juni 2016).

Berdasarkan tabel 4 dapat diketahui bahwa variabel yang dapat digunakan untuk memprediksi atau berkontribusi terhadap perilaku agresif adalah variabel fungsi, dukungan, dan lingkungan keluarga dengan korelasi sebesar 0,$231 ; 0,247$; dan 0,227. Sehingga dapat ditentukan bentuk umum persamaan regresi linier berganda yaitu: perilaku agresif $=119,730-(0,390$ fungsi keluarga) - (0,188 dukungan keluarga) $(0,261$ lingkungan keluarga).

Persamaan selanjutnya dilakukan uji ANOVA dan dilihat hasil Summary Model untuk mengetahui kelayakan persamaan dan seberapa besar nilai persen kepercayaan persamaan menjelaskan presiksi. Dari tabel 6 didapatkan hasil $p$-val pada uji ANOVA $=0,000$ $<0,05$ dan hasil Model Summary Adjusted $R$ Square $\left(R^{2}\right)$ adalah 0,24 atau $24 \%$ yang artinya persamaan yang diperoleh layak digunakan dan mampu menjelaskan perilaku agresif variabel lain.

Sebelum dilakukan pengujian hipotesis regresi ada beberapa uji asumsi klasik yang harus dipenuhi agar kesimpulan dari regresi tersebut tidak bias, yaitu uji normalitas, uji multikolinieritas, uji autokorelasi, uji heteroskodesitas dan uji linieritas. Dari pengujian asumsi klasik didapatkan hasil prasyarat terpenuhi, sehingga dapat disimpulkan bahwa secara bersama-sama faktor fungsi, dukungan, dan lingkungan keluarga berhubungan secara bermakna dengan perilaku agresif. Peningkatan faktor fungsi, dukungan dan lingkungan keluarga akan menurunkan perilaku agresif. Dan faktor fungsi keluarga adalah yang paling berkontribusi atau berhubungan dengan perilaku agresif sebesar 0,390.

\section{PEMBAHASAN}

Penelitian ini menjelaskan tentang hubungan faktor-faktor keluarga (fungsi , dukungan, dan lingkungan keluarga) dengan perilaku agresif pada remaja di Kota Malang dengan pendekatan teori struktural fungsional keluarga.

Faktor Keluarga (fungsi,dukungan,lingkungan) dan Perilaku Agresif.

Dari tabel 1 pada variabel fungsi keluarga didapatkan rata-rata skor mean sebesar 36,24 
(59\%) dalam kategori fungsional keluarga. Pernyataan tersebut didukung dengan data umum penelitian yang menunjukkan bahwa sebagian besar pendidikan orang tua adalah SMA, bekerja, pendapatan orang tua rata-rata UMR.Temuan penelitian ini didukung dengan pernyataan yang disampaikan oleh Notoadmodjo (2010) yang menyatakan bahwa pendidikan dapat mempengaruhi seseorang termasuk juga perilaku seseorang dalam memotivasi untuk bersikap serta berperan dalam kehidupan sehari-hari.

Sedangkan pada variabel dukungan keluarga didapatkan rata-rata skor mean sebesar 58,13 (58\%) kategori dukungan keluarga sedang. Temuan penelitian menunjukkan bahwa sebagian besar orang tua bekerja, pendidikan SMA dan memiliki pendapatan rata-rata UMR. Friedman (2010) menyatakan bahwa kelas sosial ekonomi orang tua mempengaruhi dukungan keluarga. Dalam keluarga kelas menengah, suatu hubungan lebih demokratis, afeksi dan keterlibatan orang tua juga akan lebih tinggi dibandingkan dengan kelas sosial ekonomi bawah.

Dan berdasarkan variabel lingkungan keluarga didapatkan rata-rata skor mean sebesar 72,18 (94\%) kategori lingkungan keluarga sucturedness. Yaitu lingkungan keluarga yang menekankan adanya aturan-aturan keluarga atau disiplin, berorientasi pada tujuan didalam keluarga, keteraturan serta pencapaian prestasi oleh masing-masing anggota keluarganya (Saucier, Wilson, Warka, 2007).

Berdasarkan narasi gambaran umum respinden diketahui bahwa sebagian besar orang tua tinggal serumah, bekerja, pendidikan SMA dan memiliki pendapatan rata-rata UMR. Hasil penelitian ini diasumsikan bahwa orang tua dapat menyediakan lingkungan rumah yang mendukung untuk perkembangan remaja. Temuan penelitian ini didukung dengan pernyataan Gunarsa (2009) yang menyatakan bahwa dilingkungan keluarga atau dirumah peranan orang tua (ayah dan ibu) sangat mempengaruhi pembentukan sikap dan disiplin pada anak. Yang dilakukan melalui pemberian contoh seperti kasih sayang orang tua, keteladanan, keharmonisan dan keutuhan dalam keluarga. Orang tua yang tinggal terpisah karena perceraian dapat meyebabkan ketidak harmonisan dalam lingkungan keluarga. Yang berdampak pada cara pengasuhan kepada remaja seperti kurangnya kasih sayang, dan keteladanan (Gunarsa, 2009).

Sedangkan pada tabel 2 pada variabel perilaku agresif didapatkan rata-rata skor (mean) sebesar 76,24 (75\%) kategori perilaku agresif diatas rata-rata. Selain itu pada tabel 1 dan 2 
diketahui bahwa sebagian besar remaja berusia 13 tahun (remaja awal), jenis kelamin laki-laki, dan mudah emosi, pernah mengalami paparan kekerasan, sering menjumpai paparan kekerasan disekolah, dan mencontoh perilaku agresif dari teman disekolah

Temuan hasil penelitian ini diasumsikan bahwa remaja yang sedang melalui fase perkembangan beresiko melakukan perilaku agresif dan mudah terpengaruh perilaku orang lain. Pernyataan ini didukung oleh Oktiawati \& Saputri (2015) yang menyebutkan bahwa remaja akan mencapai beberapa tahap salah satunya egosentrisme. Yaitu suatu kondisi dimana remaja yang awalnya memusatkan perhatian pada diri sendiri diganti dengan mengikuti orang lain atau kelompok. Sehingga perilaku kelompok menjadi dominan dalam mempengaruhi perilaku individu. Kemampuan remaja dalam fase perkembangan ini dicapai melalui serangkaian tugas perkembangan. Ketidak berhasilan dalam mencapai tugas ini dapat menyebabkan kebingungan peran. Yang berdampak pada rapuhnya kepribadian sehingga remaja mudah mengadaptasi perilaku negatif seperti perilaku agresif.

\section{Korelasi fungsi dengan perilaku agresif.}

Hasil penelitian tabel 3 variabel korelasi fungsi keluarga dengan perilaku agresif didapatkan nilai signifikansi $p$ value $=0,001<\alpha 0,05$ dan koefisien korelasi $(r)=-0,361$ (berada di range $0,2-<0,4)$. Yang artinya Ho ditolak atau H1 diterima, dengan arah hubungan bertanda negatif (-). Sehingga dapat disimpulkan ada hubungan yang bermakna sebesar 0,361 atau lemah antara peningkatan fungsi keluarga dengan penurunan perilaku agresif.

Dalam penelitian ini juga diketahui bahwa sebagian besar responden dengan kategori fungsional keluarga dengan skor perilaku agresif diatas rata-rata. Temuan penelitian ini diasumsikan bahwa fungsi keluarga tidak hanya tentang peran orang tua namun bagaimana kualitas peran orang tua. Pernyataan ini didukung oleh Stuart, Keliat, \& Pasaribu (2016) yang menyebutkan bahwa pada dasarnya perilaku agresif yang dilakukan remaja disebabkan adanya manajemen keluarga yang tidak terorganisir, kurangnya pengawasan orang tua, paksaan dalam mengontrol remaja, serta rendahnya tingkat keterlibatan pada remaja.

Selain itu Moos\&Moos dalam Stuart (2009) menyebutkan suatu fungsi keluarga dikatakan fungsional tidak hanya dari cara orang tua menjalankan fungsinya akan tetapi keberfungsian keluarga ditandai dengan karakteristik bagaimana kualitas komunikasi antar anggotanya, serta bagaimana antar anggotanya meluangkan waktu dan saling 
memberikan dukungan satu sama lain.

\section{Korelasi dukungan dengan perilaku agresif}

Pada tabel 3 variabel korelasi dukungan keluarga dengan perilaku agresif didapatkan signifikansi $p$ value $=0,000<\alpha 0,05$ dan koefisien korelasi $(r)=-$ 0,416 (berada di range $0,4-<0,6$ ). Yang artinya Ho ditolak atau H1 diterima dengan arah hubungan bertanda negatif (-). Sehingga dapat disimpulkan ada hubungan yang bermakna sebesar 0,416 atau sedang antara peningkatan dukungan keluarga dengan penurunan perilaku agresif.

Selain itu dalam penelitian ini juga diketahui bahwa sebagian besar responden dengan kategori dukungan sedang dan skor perilaku agresif diatas rata-rata.

Temuan penelitian ini diasumsikan karena sebagian besar remaja tidak memperoleh dukungan yang optimal dari orang tua sehingga remaja lebih mudah terpengaruh perilaku negative. Temuan penelitian ini didukung dengan pernyataan Videbeck (2008) yang menyatakan bahwa dukungan orang tua kepada anak memiliki peranan penting untuk mencegah anak dari ancaman kesehatan mental. Misalnya respon emosional yang dapat dimanifestasikan dalam berbagai macam bentuk perilaku negatif.

Menurut pendekatan psikopatologi perilaku agresif muncul akibat stres dan depresi yang terjadi secara spontan. Namun prosesnya telah berlangsung lama atau dalam periode waktu tertentu (I Wahdan, et al, 2013). Kondisi ini terjadi saat remaja dihadapkan dengan stimulus sosial tertentu. Individu yang memperoleh dukungan tinggi akan memiliki ketrampilan interpersonal (interpersonal skill) yang lebih tinggi sehingga akan lebih mudah beradaptasi dengan stress (Calvete \& Orue, 2012).

\section{Korelasi lingkungan dengan perilaku agresif.}

Berdasarkan tabel 3 pada variabel korelasi lingkungan keluarga dengan perilaku agresif didapatkan nilai signifikansi $p$ value $=0,000<\alpha$ 0,05 dan koefisien korelasi $(r)=-0,379$ (berada di range $0,2-<0,4)$. Yang artinya Ho ditolak atau $\mathrm{H} 1$ diterima dengan arah hubungan bertanda negatif (-). Sehingga dapat disimpulkan ada hubungan yang bermakna sebesar 0,379 atau lemah antara peningkatan lingkungan keluarga dengan penurunan perilaku agresif.

Hasil penelitian pada tabel 1 dan 2, didapatkan data sebagian besar responden dalam kategori lingkungan structuredness dan skor perilaku agresif diatas rata-rata. Dan data umum responden menunjukkan bahwa sebagian besar remaja pernah mengalami riwayat terpapar perilaku agresif di sekolah, dan melakukan perilaku agresif karena teman disekolah.

Temuan penelitian ini dapat diasumsikan bahwa perilaku remaja dapat dipengaruhi oleh lingkungan diluar keluarga yaitu sekolah. Pernyataan ini didukung oleh Shurbanovska (2013), yang menyebutkan banyak faktor yang menyebabkan perilaku agresif pada remaja. Namun diduga kuat berhubungan dengan faktor lingkungan dan keluarga. Menurut Todd \& et.al, dalam Nataliani (2010) 
perilaku gresif di kalangan siswa telah menjadi sebuah masalah yang serius di berbagai negara diseluruh dunia. Semakin sering siswa dihadapkan dengan perilaku agresif akan berkembang persepsi bahwa hal tersebut merupakan perilaku yang biasa saja.

Anak - anak yang tumbuh dalam lingkungan yang penuh kekerasan akan berperilaku yang sama karena mereka telah terbiasa dengan cara-cara tersebut. Mereka juga berpikir bahwa cara berinteraksi dengan orang lain adalah dengan cara yang keras (Sijtsema, 2013).

\section{Faktor yang paling berhubungan dengan perilaku agresif.}

Berdasarkan tabel 4 tentang hasil analisis multivariat dapat diketahui bahwa variabel fungsi keluarga diprediksi paling berhubungan atau paling berkontribusi terhadap perilaku agresif pada remaja sebesar 0,390. Hasil penelitian ini dapat diasumsikan bahwa nyatanya peranan dan kulitas hubungan orang tua dengan remaja sangat penting dalam pengasuhan remaja.

Pernyataan ini didukung oleh Yusuf (2014) yang menyatakan bahwa fungsi keluarga tidak hanya sebatas keluarga memerankan perannya akan tetapi bagaimana antar anggotanya mengembangkan rasa memiliki, rasa aman, kasih sayang, dan mengembangkan hubungan yang baik antar anggotanya.
Murdock dalam DeGenova (2008) menyebutkan bahwa keluarga inti menjalankan fungsi untuk meyediakan tempat tinggal dan lingkungan untuk tumbuh kembang. Seperti yang telah dibahas pada sub bab sebelumnya tentang korelasi fungsi keluarga dengan perilaku agresif, didapatkan hasil bahwa disfungsi keluarga ringan menyebabkan respon psikologis yang berbeda-beda. Termasuk bagaimana mereka mengekspresikan perilaku emosinya. Disfungsi keluarga dapat disebabkan karena ketidak harmonisan keluarga sehingga mempengaruhi struktur dan fungsi didalam keluarga.

Menurut pendekatan teori keluarga dalam model struktural fungsional keluarga disebutkan bahwa perubahan struktur dan fungsi organisasi keluarga dan proses umpan balik di antara anggotanya maka akan mengubah fungsi individu di dalamnya(Ballard, Kennedy, \& O’Brien, 2014).

Minuchin (1974) dalam Ballard, Kennedy, \& O’Brien (2014) menjelaskan pula tentang teori struktural fungsional keluarga dimana keberfungsian keluarga tercermin dari struktur dan fungsi keluarga. Hal ini dapat membantu menganalisa kondisi sebuah keluarga berdasarkan tiga komponen.

Pertama adalah struktur keluarga. Diartikan sebagai cara anggota keluarga dapat saling berinteraksi. Didalamnya terdapat tiga 
subsistem yaitu ayah, ibu dan anak. Dalam subsistem tersebut terdapat komponen tanggung jawab seperti sebagai orang tua memiliki tanggung jawab dalam pengawasan dan pemeliharaan terhadap anak.

Pernyataan ini sesuai dengan hasil penelitian yang menunjukkan sebagian besar keluarga funsional, orang tua tinggal serumah. Hal ini diasumsikan bahwa orang tua dapat melaksanakan peran sesuai kedudukannya dengan baik dalam pengasuhan remaja.

Kedua adalah perkembangan keluarga, keluarga berkembang dari masa kemasa dan memerlukan perbaikan. Adanya perubahan pada komponen yang pertama akan mempengaruhi perkembangan pada masa selanjutnya.

Pernyataan ini sesuai dengan hasil penelitian yang menyebutkan bahwa sebagian besar remaja sebelumnya pernah terpapar dengan perilaku agresif. Hal ini diasumsikan bahwa remaja mempelajari perilaku tersebut dan melakukannya kembali.

Komponen ketiga adalah keluarga mampu beradaptasi dengan perubahan untuk menjaga kelangsungan dan kesejahteraan anggota keluarganya. Hal ini diasumsikan bahwa perilaku agresif pada remaja harus segera ditangani untuk mencegah terjadinya perilaku menyimpang yang lain. Pernyataan tersebut didukung juga oleh Sijtsema, et al, (2013) bahwa perilaku agresif harus ditangani hal ini dimaksudkan agar remaja memperoleh ketrampilan baru sehingga remaja dapat menjadi lebih adaptif terhadap adanya stressor.

Dari pernyataan diatas dapat disimpulkan bahwa hasil penelitian sesuai dengan teori. Dan pendekatan teori stuktural fungsional keluarga sangat tepat digunakan untuk menganalisa hubungan faktor keluarga dengan perilaku agresif pada remaja. Karena pada dasarnya keberfungsian sebuah keluarga tidak hanya ditentukan oleh bagaimana orang tua melaksanakan perannya kepada remaja akan tetapi bagaimana orang tua hadir untuk remaja memberikan dukungan kepada remaja dalam bentuk perhatian, kasih sayang, cinta kasih, dan komunikasi. Serta bagaimana orang tua menyedikan lingkungan atau rumah yang dinamis, memiliki keteraturan, disiplin serta mengupayakan prestasi bagi remaja untuk perkembangannya.

Hasil penelitian memiliki implikasi kepada orang tua untuk mencegah perilaku agresif dengan mempertahankan fungsi, dukungan dan lingkungan keluarga. Kepada sekolah sebagai dasar penanganan bagi untuk mengurangi perilaku agresif melalui peran guru dalam memberikan keteladanan. Bagi profesi meningkatkan upaya promotif 
mencegah terjadinya perilaku agresif perilaku agresif.

khususnya pada kelompok khusus remaja. Bagi peneliti selanjutnya dapat dijadikan evidence based dalam penanganan perilaku agresif khususnya pada remaja.

terdapat keterbatasan dalam penelitian ini yaitu responden hanya dibatasi pada siswa yang tercatat melakukan pelanggaran disekolah sehingga dimungkinkan lebih banyak lagi siswa yang melakukan perilaku agresif di luar lingkungan sekolah yang tidak bisa terjaring. Instrumen yang digunakan adalah kuisioner sehingga dipengaruhi kejujuran responden pada waktu menjawab pertanyaan kuisioner.

\section{KESIMPULAN}

Secara bersama-sama faktor fungsi, dukungan, dan lingkungan keluarga berhubungan secara bermakna dengan perilaku agresif. Peningkatan faktor fungsi, dukungan dan lingkungan keluarga akan menurunkan perilaku agresif. Faktor fungsi keluarga merupakan faktor yang paling berkontribusi atau berhubungan dengan

\section{DAFTAR PUSTAKA}

Ballard, Karen A.,Kennedy, Winifred Z.,\& O'Brien, Patricia G.(2014). Keperawatan kesehatan jiwa psikiatrik: teori \& praktik. Jakarta : EGC.

Caicedo, Beatriz, \& Jones, Kelvin. (2014). The role of neighborhood, family and peer regarding Colombian adolescents social context and aggresive behaviour. Revista de salud publica, 16(2), 208-220. Calvete, Esther, \& Orue, Izaskun. (2012). Social information processing as a 
mediator between cognitive schemas and aggressive behavior in adolescents. Journal Abnorm child psychol, 40, 105117.

Dewi, Rizki Cintya, Oktiawati, Anisa, \& Saputri, Lintang Dewi. (2015). Teori\&Konsep tumbuh kembang bayi, toddler, anak dan usia remaja. Yogyakarta: Nuha Medika.

DeGenova, M.K.(2008). Intimate relationship, marriage and families. New York: Mc.Graw Hill.

Fagel, Selene, Sonneville, Leo de, Engeland, Herman van, \& Swaab, Hanna. (2014). School-associated problem behavior in childhood and adolescence and development of adult schizotypal symmptoms:a follow-up of a clinical cohort. Journal Abnorm child psychol, $42,813-823$

Fitzgerald-Yau, Natasha, \& Viner, Russel Mark. (2014). A systematic review of effective interventions for reducing multiple health risk behaviors in adolescence. American journal of public helath, 105(5), 19-41.

Friedman, Marylin M. (2010). Keperawatan keluarga teori dan praktik. Edisi 3.Jakarta:EGC.

Gunarsa, Singgih D.(2009). Psikologi perkembangan anak dan remaja.
Jakarta: PT.BPK Gunung Mulia.

I.Wahdan, N., U-Nimr, Kotb, R., \& Wahdan, A. (2013). Risk of aggressiion on criminal behaviour among adolescent living in Alexandria Governorate, Egypt. Eastern meditemanean health journal, 20(4), 265-272.

Keliat, Budi Anna et al.(2013). Keperawatan kesehatan jiwa komunitas:CMHN (Basic Course). Jakarta: EGC.

Mazefsky, Carla A., \& Farrell, Albert D. (2011). The role of witnessing violence, peer provocation, family support and parenting practice in the aggressive behaviour of rural adolescents. Journal of child and family studies, 14(1), 71-85.

Notoadmodjo, S.(2010). Ilmu Perilaku Kesehatan.Jakarta: Rineka Cipta.

Shurbanovska, Orhideja. (2013). Parents and friends as factors of childs behavior at school: a comparison of multiple correlations. International journal of cognitive research in science, engineering and education, 1(1).

Sijtsema, Jelle JuritEllis, Bruce J, Nederhof, Esther, Ormel, Johan, Oldehinkel, Albertine J., \& Veenstra, Rene. (2013). Effects of family cohesion and heart rate reactivity on aggressive/rule-breaking behavior and prosocial behavior in adolescence:The Tracking Adolescents' 
Individual Lives Survey study. Journal development and psychopathology, 25, 699-712.

Sijtsema, J.J, Oldehinkel, A.J, Veenstra, R., Verhulst, F.C, \& Ormel, J. (2014). Effect of structural and dynamic family characteristics on the development of depressive and aggressive problems during adolescence.The Trail study. Journal Eur adolesc psychiatry, 23, 499513.

Stuart, Gail W., Keliat, Budi A., \& Pasaribu, Jesika.(2013). Prinsip dan praktik keperawatan kesehatan jiwa stuart. Edisi Indonesia(Buku 1). Singapura: Elsevier.
Stuart, G.W., Laraia.(2009). Principles and practice of psychiatric nursing. St.Louis: Mosby YearB.

Videbeck, Sheila L.(2008). Buku Ajar Keperawatan Jiwa.Jakarta:EGC

Williford, Anne Powell, Bank, Shandra Forrest, Bender, Kimberly A., Brisson, Daniel, \& Jenson, Jeffrey M. (2011). Patterns of aggressive behavior to early and peer victimization from childhood to early adolescence:A latent class analysis. Journl youth adolescence, 40, 644-655.

$\begin{array}{lrr}\text { Yusuf, } & \text { Syamsu.(2004). } & \text { PSikologi } \\ \text { perkembangan } & \text { anak } & \text { dan } \\ \text { remaja.Bandung: } & & \text { PT.Remaja } \\ \text { Rosdakarya. } & & \end{array}$

